\title{
Nation, Religion, Gender: The Triple Challenge of Middle-Class German-Jewish Women in World War I
}

\author{
Martina Steer
}

ABSTRACT. German-Jewish women are elusive figures in the current literature on World War I. Looking at the complexity of their wartime experience and its consequences for the Weimar years, this article deals with Jewish middle-class women's tripartite motivation as Germans, Jews, and females to make sacrifices for the war. To that end, it traces their efforts to help Germany to victory, to gain suffrage, and to become integrated into German society. At the same time, the article shows how these women not only transformed the war into an opportunity for greater female selfdetermination but also responded to wartime and postwar antisemitism. The experience of the war and the need for reorientation after 1918 motivated them to become more involved in the affairs of the German-Jewish community itself and to contribute significantly to shaping public Jewish life in Weimar Germany—but without giving up their German identity.

Deutsche Jüdinnen sind aus verschiedenen Gründen nur schwer in der aktuellen Literatur über den Ersten Weltkrieg auszumachen. Anhand der Komplexität der jüdischen Kriegserfahrung und deren Konsequenzen für die Weimarer Jahre handelt dieser Artikel von der dreifachen Motivation der jüdischen Frauen als Deutsche, Jüdinnen und Frauen, Opfer für den Krieg zu erbringen. Dabei analysiert er ihre Versuche, zum deutschen Sieg beizutragen, das Frauenwahlrecht zu erringen und als Jüdinnen voll in die deutsche Gesellschaft integriert zu werden. Darüber hinaus wird aufgezeigt, wie die Frauen den Krieg aktiv dafür nutzen, ihre Handlungsspielräume zu vergrößern, gleichzeitig aber sich mit dem Antisemitismus der Kriegs- und Nachkriegsjahre auseinandersetzen und Gegenstrategien entwickeln mussten. Es wird dabei deutlich, dass das Kriegserlebnis und die Situation nach 1918 die Frauen dazu motivierten, sich mehr und mehr bei der Neuorientierung der deutsch-jüdischen Gemeinschaft einzubringen und öffentliches jüdisches Leben in den Weimarer Republik aktiv zu gestalten—ohne ihre deutsche Identität aufzugeben.

$\mathrm{T}$ HE experience of World War I for German society sowed the seeds of some of the major political and intellectual trends of the Weimar Republic. The hopes, aspirations, and exuberant patriotism of 1914, as well as the sense of liberation individuals gained from surrendering to the national "community of fate," gradually gave way to uncertainty, fear, mass bereavement, starvation, disappointment, and military defeat. Most German Jews experienced all this along with their fellow Germans, but the war had an additional level of significance for them. As the historiography of German Jewry has pointed out, German Jews underwent a "distinct change in awareness" during the war, adopting a " "post-assimilatory' identity that ... had a lasting impact on the self-image and cultural and intellectual endeavors of German Jewry."1

I want to thank the two anonymous reviewers for their careful reading of earlier versions of this article. Their comments prompted me to rethink my approach. Producing an academic text in a foreign language is a challenge for all non-native speakers; special thanks is also due to CEH editor-in-chief Andrew I. Port, who turned my manuscript into a more coherent piece of scholarly work. I deeply appreciate his critical insight, stylistic sense, and kindness.

${ }^{1}$ Translated by the author from Paul Mendes-Flohr, "Im Schatten des ersten Weltkrieges," in Deutsch-jüdische Geschichte in der Neuzeit, vol. 4, Aufbruch und Zerstörung, 1918-1945, ed. Michael A. Meyer (Munich: C. H. Beck, 1997), 15-36. On the change in awareness among German Jews, see Eva G. Reichmann, "Der Bewusstseinswandel der deutschen Juden," in 
This article focuses on the analogous change in awareness that middle-class German-Jewish women in particular went through at this time. It identifies the indicators of and triggers for their radical reorientation; further, it shows how that reorientation manifested itself in their behavioral strategies and had serious repercussions. The article deals, above all, with Jewish women's tripartite motivation as Germans, Jews, and females to make sacrifices for the war, showing that although their attempts to help Germany to victory and to become integrated in German society were futile, they nevertheless benefited from Germany's political and social transformation after 1918. Shedding light on generational and ideological conflicts, the article also looks at the early Weimar years to explore the different ways in which German-Jewish middle-class women reacted to the traumatic experience of the war and to their increasingly ambivalent situation in the postwar years. Finally, the article argues that although bourgeois German-Jewish women gradually distanced themselves as Jews from German public discourse, even withdrawing from German society as a result of the rising tide of antisemitism, they nevertheless became ever more active in the formation of a German-Jewish sense of community.

The Jüdischer Frauenbund (Jewish Women's League, JFB) serves as a case study for the changing attitudes of middle-class German-Jewish women. With membership totaling fifty thousand in 1928, the JFB represented between 15 and 20 percent of all German-Jewish women and was the third largest Jewish organization in the German Reich after the Reichsverband jüdischer Frontsoldaten (Reich Union of Jewish Frontline Soldiers, RjF) and the Centralverein deutscher Staatsbürger jüdischen Glaubens (Central Association of German Citizens of Jewish Faith, CV). ${ }^{2}$ The JFB can be considered suitably representative of German-Jewish women in general not only because many of them were members but also because of their social backgrounds: most of the JFB's members were middle-class housewives. This reflected the social profile of German Jewry at the time, which was predominantly middle class in financial and cultural terms. ${ }^{3}$

The JFB's membership rose sharply during and after World War I. In 1913, before the outbreak of the war, the organization had some 30,000 members and was made up of 160 subsidiary groups. By 1917, it had 215 such groups, 10 local branches, and 44,000 members, and it continued to grow throughout the 1920s. The number of subsidiary groups would rise to 430 by 1928 , with 34 local branches and 50,000 members. Yet, it seems to have had great difficulty recruiting younger members. ${ }^{4}$ Why, then, did the JFB's membership rise rather than fall? The growing number of members - despite the lack of young recruits - points to the fact that, during and after the war, mostly older women joined the JFB. This article explores what happened during the war years to prompt so many older women to join the JFB and examines how this aging membership influenced the organization's program and orientation.

As we shall see, the JFB's prewar and postwar objectives changed along with its membership. The organization was founded by Bertha Pappenheim in 1904-a time when the women's movement was gaining ground and a number of religious women's associations were

\footnotetext{
Deutsches Judentum in Krieg und Revolution 1916-1923, ed. Werner E. Mosse and Arnold Paucker (Tübingen: Mohr Siebeck, 1971), 511-612.

${ }^{2}$ Allgemeine Zeitung des Judentums (AZJ), April 1913, supplement "Der Gemeindebote"; AZJ, Feb. 1917, supplement "Der Gemeindebote"; Blätter des Jüdischen Frauenbundes (BJFB), Jan. 1928.

${ }^{3}$ Monika Richarz, "Berufliche und soziale Struktur," in Deutsch-jüdische Geschichte in der Neuzeit, vol. 3, Umstrittene Integration, 1871-1918, ed. Michael A. Meyer (Munich: C. H. Beck, 1997), 68. This does not imply, however, that middle-class German Jews constituted a homogeneous group in financial terms. In the late nineteenth century and the first half of the twentieth century, the gap between the Jewish upper- and lower-middle-classes increased. See Till van Rahden, Juden und andere Breslauer. Die Beziehungen zwischen Juden, Protestanten und Katholiken in einer deutschen Großstadt zwischen 1860 und 1925 (Göttingen: Vandenhoeck \& Ruprecht, 2000), 46.

${ }^{4}$ Marion Kaplan, Die jüdische Frauenbewegung in Deutschland. Organisation und Ziele des Jüdischen Frauenbundes 1904-1938, trans. Hainer Kober (Hamburg: Christians, 1981), 119-20.
} 
established. ${ }^{5}$ The JFB aligned itself with this movement and joined the Bund Deutscher Frauenvereine (Union of German Women's Associations, BDF) in 1907. ${ }^{6}$ While both organizations embraced moderate feminism, the JFB addressed issues specifically relevant to Jewish women and, like the CV, responded directly to the militant antisemitism that could be observed across the Reich around the turn of the century. The JFB's founding statutes describe its two main fields of activity. The first involved "motivating each other to serve the public good" by providing "social assistance" and "popular education," "supporting the working lives of Jewish women and girls," "improving morality," and "fighting female slavery." The second was aimed at "awakening interest in general Jewish endeavors today, and strengthening the Jewish sense of community."7

At the time of its founding in 1904, the JFB declared the fight against antisemitism to be one of its "main objectives." This point was not included in its statutes, however, until 1917, when, as a reaction to the visible rise in antisemitic agitation, it was inscribed under Point $1, \mathbb{} 2$, section $\mathrm{f}^{8}$ Over the course of the war and throughout the postwar years, the JFB concentrated its efforts less on combating female trafficking and prostitution and more on campaigning for women's right to vote in Jewish communities (it had previously discussed equality in Jewish communities in only general terms). ${ }^{9}$ Similarly, after 1918, the JFB started working actively to support international reconciliation. At the same time, it abandoned its previous strictly anti-Zionist course to embrace Zionist activities and initiatives. ${ }^{10}$ In short, the JFB became more concerned with specifically Jewish matters - in Germany and internationally - than with women's issues, which had been one of its main raisons d'être before $1918 .{ }^{11}$ What caused the JFB to alter its program and concentrate primarily on Jewish affairs toward the end of the war and during the Weimar years?

The JFB and the German-Jewish women who lived through World War I remain, in many respects, elusive figures. The historiography of German-speaking Jewry during the war focuses on Jewish soldiers in the trenches and their fight against the military enemy as well as the antisemitism of their non-Jewish comrades, and on the struggle of male intellectuals such as Martin Buber, Leo Baeck, and Karl Wolfskehl to incorporate the new situation into their philosophical ideas. ${ }^{12}$

\footnotetext{
${ }^{5}$ The Deutsch-Evangelischer Frauenbund (German-Protestant Women's League, DEFB) was founded in 1899, the Katholischer Frauenbund (Catholic Women's League, KFB) in 1903. On the history of these organizations, see, e.g., Ursula Baumann, Protestantismus und Frauenemanzipation in Deutschland, 1850-1920 (Frankfurt/Main: Campus, 1992); Gisela Breuer, Frauenbewegung im Katholizismus. Der Katholische Frauenbund, 1903-1918 (Frankfurt/Main: Campus, 1998).

${ }^{6}$ The Bund Deutscher Frauenvereine (BDF) was founded in 1894 to promote the common interests of German women. As of 1914, it had over five hundred thousand members. See Ute Frevert, Frauen-Geschichte. Zwischen bürgerlicher Verbesserung und neuer Weiblichkeit (Frankfurt/Main: Suhrkamp, 1986), 109. Although the BDF was initially a "moderate" organization, it shifted ever further to the right politically over the course of its existence. The JFB nevertheless remained affiliated with the BDF until shortly before the latter was dissolved on May 15, 1933. See Barbara Greven-Aschoff, Die bürgerliche Frauenbewegung in Deutschland, 1894-1933 (Göttingen: Vandenhoeck \& Ruprecht, 1981), 188. Several positions on the board of the BDF were held by Jewish women, among them Ika Freudenberg, Bertha Pappenheim, Alice Bensheimer, Josephine Levy-Rathenau, and Marie Bernays.

7 "Der jüdische Frauenbund," AZJ, June 1904.

${ }^{8}$ Landesarchiv Berlin (LAB), B Rep. 235-20 MF 1183 Helene-Lange-Archiv, "Statuten des JFB 1917."

${ }^{9}$ Neither the general demand for gender equality in appointments to community posts nor the demand for women's right to vote in the communities appears in the JFB's statutes of 1917.

${ }^{10}$ Kaplan, Die jüdische Frauenbewegung, 124.

${ }^{11}$ Ibid., 123.

${ }^{12}$ See, e.g., Werner E. Mosse and Arnol Paucker, eds., Deutsches Judentum in Krieg und Revolution 1916-1923 (Tübingen: Mohr, 1971); Peter Pulzer, Jews and the German State: The Political History of a Minority, 1848-1933 (Oxford: Blackwell, 1992); Martin Welling, "'Wie ein böser Spuk'. Düsseldorfer Juden in Krieg und Revolution 1914-1920," Aschkenas 13, no. 1 (2003): 167-88; Michael Berger, Eisernes Kreuz und Davidstern. Die Geschichte jüdischer Soldaten in deutschen Armeen (Berlin: Trafo, 2006); Todd Pressner, "Muscle Jews and Airplanes: Modernist Mythologies, the Great War, and the Politics of Regeneration," Modernism/Modernity 13, no. 4 (2006): 701-28; Jacob Rosenthal, "Die Ehre des jüdischen Soldaten”. Die Judenzählung im Ersten Weltkrieg und ihre Folgen (Frankfurt/Main: Campus, 2006); Tim Grady, The German-Jewish Soldiers of the First World War in History and Memory (Liverpool: Liverpool University Press, 2011); David J. Fine, Jewish Integration in the German Army in the First World War (Berlin: De Gruyter, 2012); Derek Penslar, Jews and
} 
In-depth research into the history of women during World War I still does not extend beyond the feminist historiography of the 1990s. ${ }^{13}$ But even the extant research into the histories of (German) women - not only during World War I - presumes a degree of homogeneity within the female population that did not exist. In keeping with the conventions of social history, such research differentiates between the women's social classes but explores their religion and ethnicity only peripherally. ${ }^{14}$ Certainly, Jewish men and women were a tiny-though visible-minority, constituting only 1 percent of the total German population (i.e., just over five hundred thousand individuals). The balance was different within the bourgeois German women's movement, however: with well over fifty thousand members, the JFB was the largest single organization of the BDF, and its omission from research literature is thus an oversight that must be remedied.

In fact, the literature has largely neglected German-Jewish women's history during World War I as a whole. Marion Kaplan provides a ten-page overview of the war years in her work on the Jewish middle class in the German Empire, and her pioneering work on the JFB documents the history of the organization from 1904 to $1938 .{ }^{15}$ But she deals with the period between 1914 and 1918 in just a single sentence: "During World War I the JFB subordinated its immediate objectives to the war effort." 16 Other scholars active in the field of German-Jewish women's history similarly devote little attention to World War I in their works. ${ }^{17}$ This is unsurprising, for the existing source material does not facilitate research about the wartime period. The JFB archive no longer exists, for one, and the availability of its material is poor. ${ }^{18}$ As a result, one must rely on autobiographies, journals, and the organization's own bulletin, the Blätter des Jüdischen Frauenbundes (BJFB), to trace its history. ${ }^{19}$ Published regularly beginning in 1924, the

the Military: A History (Princeton, NJ: Princeton University Press, 2013); Brian E. Crim, Antisemitism in the German Military Community and the Jewish Response, 1914-1938 (Lanham, MD: Lexington Books, 2014); Sarah Panter, Jüdische Erfahrungen und Loyalitätskonflikte im Ersten Weltkrieg (Göttingen: Vandenhoeck \& Ruprecht, 2014). Panter's very thorough research rebuts the common assumption that antisemitic incidents were rare in the trenches; she studied archival material from the CV-anonymous letters and correspondence with the military authorities - that had never been used before. Also see Ulrich Sieg, Jüdische Intellektuelle im Ersten Weltkrieg. Kriegserfahrungen, weltanschauliche Debatten und kulturelle Neuentwürfe (Berlin: Akademie-Verlag, 2001).

${ }^{13}$ See, e.g., Greven-Aschoff, Die bürgerliche Frauenbewegung, 10; Richard Wall and Jay Winter, eds., The Upheaval of War: Family, Work and Welfare in Europe, 1914-1918 (Cambridge: Cambridge University Press, 1988); Sabine Hering, Die Kriegsgewinnlerinnen. Praxis und Ideologie der deutschen Frauenbewegung im Ersten Weltkrieg (Pfaffenweiler: CentaurusVerlags-Gesellschaft, 1990); Birthe Kundrus, Kriegerfrauen. Familienpolitik und Geschlechterverhältnisse im Ersten und Zweiten Weltkrieg (Hamburg: Christians, 1995); Belinda Davis, Homes Fires Burning: Food, Politics, and Everyday Life in World War I Berlin (Chapel Hill: University of North Carolina Press, 2000). Jay Winter and Jean Louis Robert's two-volume anthology on the cities of London, Paris, and Berlin during World War I was the first to make the home front the focus of international research, but this work does not examine issues that were primarily relevant to women, including prostitution and child care. See Jay Winter and Jean-Louis Robert, eds., Capital Cities at War: Paris, London, Berlin 1914-1919, vol. 1 (Cambridge: Cambridge University Press, 1999).

${ }^{14}$ Even the latest research is not an exception here: Myra Marx Ferree's book on German feminist politics in a global context addresses the role of the DEFB within the BDF but not the role of the considerably larger JFB. See her Varieties of Feminism: German Gender Politics in a Global Perspective (Stanford, CA: Stanford University Press, 2012).

${ }^{15}$ Marion Kaplan, The Making of the Jewish Middle Class: Women, Family, and Identity in Imperial Germany (New York: Oxford University Press, 1991); Kaplan, Die jüdische Frauenbewegung.

${ }^{16}$ Kaplan, Die jüdische Frauenbewegung, 123.

${ }^{17}$ See, e.g., Irmgard M. Fassmann, Jüdinnen in der deutschen Frauenbewegung, 1865-1919 (Hildesheim: Olms, 1996); Nelly Las, Jewish Women in a Changing World: A History of the International Council of Jewish Women (ICJW), 1899-1995 (Jerusalem: Avraham Harman Institute of Contemporary Jewry, 1996).

${ }^{18}$ The JFB archive was destroyed during World War II. A thorough search in the Central Archives of the History of the Jewish People, the Central Zionist Archives, the Leo Baeck Institute, and major German archives-including the Bundesarchiv and branches of the Landesarchive and Hauptstaatsarchive- did not produce any more substantial source material than the sources cited in this article.

${ }^{19} \mathrm{On}$ the problem of pre-1933 Jewish autobiographies, see the outstanding study by Miriam Gebhardt, Das Familiengedächtnis. Erinnerung im deutsch-jüdischen Bürgertum, 1890-1932 (Stuttgart: Steiner, 1999). Most of the personal memoirs used as sources for German-Jewish women's history were written after 1945 and include the authors' experiences of National Socialism, which often placed the events prior to 1933 in a completely new light. 
$B J F B$ provides only retrospective information, however, about the history of the organization during the war.

A comprehensive study of the history of German-Jewish women during World War I is, therefore, long overdue. Because this article focuses on German-Jewish middle-class women, it has limited validity with respect to the situation of Eastern European women, working-class women, and women living in rural areas of the German Reich. It nevertheless traces how women in general - voluntarily or involuntarily - transformed the war into an opportunity for greater female self-determination. At the same time, it explores female responses to wartime and postwar antisemitism, and it shows that the strategies of Jewish women to cope with the war and its aftermath had severe and long-lasting consequences not only for German Jewry but also for German society as a whole. The complexity of the Jewish wartime experience and its consequences for the Weimar years will become fully apparent only when Jewish women receive fuller attention.

\section{German-Jewish Women on the Home Front}

When Kaiser Wilhelm II declared war on Russia in August 1914 and announced the so-called Burgfriede — a "civic truce" among all political forces from right to left in the German ReichGermans applauded with varying degrees of enthusiasm. ${ }^{20}$ Opinions are divided on how positively German-Jewish men and women responded to the war. Kaplan, Peter Pulzer, and MendesFlohr believe that the majority of German-Jewish men and women exuberantly welcomed the outbreak of war. ${ }^{21}$ Relying on similar sources, Ulrich Sieg arrives at a different conclusion, tracing a more heterogeneous picture of the male Jewish population in the German Reich, which, in his eyes, was far less enthusiastic about the war than previously assumed. ${ }^{22}$ This raises the question of whether middle-class German-Jewish women themselves approved of the war as strongly as the literature has hitherto suggested, and of whether opinions among them diverged as much as they did among men. Available evidence suggests otherwise, at least with respect to the former. In an editorial for the Neue Zürcher Zeitung published on August 16, 1914, the GermanJewish philosopher Margarete Susman wrote the following — almost visionary—account of what the war would bring for the population:

\footnotetext{
${ }^{20}$ Jeffrey Verhey convincingly refutes the myth of war enthusiasm in The Spirit of 1914: Militarism, Myth, and Mobilization in Germany (Cambridge: Cambridge University Press, 2006). See also the following urban and regional historical studies, which focus on the difference between urban and rural levels of enthusiasm for the war: Christian Geinitz, Kriegsfurcht und Kampfbereitschaft. Das Augusterlebnis in Freiburg. Eine Studie zum Kriegsbeginn 1914 (Essen: Klartext, 1998); Benjamin Ziemann, Front und Heimat. Ländliche Kriegserfahrung im südlichen Bayern, 1914-1923 (Essen: Klartext, 1997).

${ }^{21}$ Their arguments are based on contrasting sources. Pulzer and Mendes-Flohr refer almost exclusively to the public statements of men in articles, books, and essays, whereas Kaplan's cursory chapter on Jewish women in World War I is based on a balanced combination of internal JFB communications, public statements, and so-called ego documents. See Peter Pulzer, "Der Erste Weltkrieg," in Deutsch-jüdische Geschichte in der Neuzeit, vol. 3, Umstrittene Integration, 1871-1918, ed. Michael A. Meyer (Munich: C. H. Beck, 1997), 356-80; Mendes-Flohr, "Im Schatten des ersten Weltkrieges," 15-20; idem, "The Kriegserlebnis and Jewish Consciousness," in Jüdisches Leben in der Weimarer Republik/ Jews in the Weimar Republic, ed. Wolfgang Benz, Arnold Paucker, and Peter Pulzer (Tübingen: Mohr Siebeck, 1998), 225-37: Kaplan, The Making of the Jewish Middle Class, 286.

${ }^{22} \mathrm{Sieg}$, Jüdische Intellektuelle im Ersten Weltkrieg, 15. According to Sieg, the philosopher Margarete Susman was the only woman who made notable comments about World War I. While conceding her a role as an intelligent sparring partner for male intellectuals such as Martin Buber and Gustav Landauer, he does not mention that she published extensively on the subject and that her commentaries were well received. See Martina Steer, " ... da zeigte sich, der Mann hatte ihr keine Welt mehr anzubieten.” Margarete Susman und die Frage der Frauenemanzipation (Bochum: Dr. Dieter Winkler, 2001).
} 
It seems the monstrous has descended upon us. We live in times that are heavy with dread; we cannot just strike it away with a simple blow, and many will lose their lives and livelihoods because of it; we all see it, we all know it. Everything has changed around us; all around demands are made of us. The rulers and the government issue appeals to their peoples to prepare them for the coming events and their new, difficult duties. Individuals meet to try and grasp the situation, to understand, to join forces to protect and help those left behind. The air around us is soaked with tears; tears that have been suppressed, tears that have been shed, and those that will be shed in the future. The gravity of the moment is searing. ${ }^{23}$

Susman's prediction align with the views of other contemporary Jewish women active in Germany at the time: Rosa Luxemburg, the well-known Polish Communist pacifist who had a bourgeois background, as well as Helene Lewison, an active member of the progressive Deutscher Bund für Mutterschutz und Sexualreform (German Association for the Protection of Mothers and Sexual Reform) in the circle around radical feminist and pacifist Helene Stöcker.

It is nevertheless true that many urban middle-class Jewish women and Jewish women's organizations explicitly approved of the war. Journalist and historian Margarete Marasse spoke of a "holy war" in September 1914, citing the Old Testament and especially Josephus's portrayal of the Maccabean Revolt of 167-160 BCE as evidence that the Jewish people were distinguished by extraordinary courage and a willingness to sacrifice even their lives for a supposedly just cause: "Welcome, death for the fatherland' sounds the call today in the East and the West of the German fatherland, as it once sounded from Mount Zion and Solomon's temple." ${ }^{24}$ In place of Christian symbolism, German-Jewish men and women developed their own repertoire of symbols and metaphors in response to the situation, most of which referred to the Maccabean Revolt, as in the case of Marasse. ${ }^{25}$ In this way, they paradoxically tried to prove that German Jews were "good Germans" by citing the example of a non-German, Jewishhence "foreign"- history. German Jews apparently believed it was possible to earn a place in the German nation even if one did not belong to it because of one's origins.

Along these lines, the poem Ihr Enkel der Makkabäer ("You grandchildren of the Maccabees"), by Siegmund Katz, ends with the lines: "Your blood, too, is German blood / And German are your hearts / If you die as heroes with courageous joy / You bear the pain around German lands / Then you are the German reapers / While grandchildren of the Maccabees." 26 But no matter how emphatically German Jews invoked metaphors suggesting they had German blood, it did not change the predominant view among non-Jewish Germans that Jews were a "foreign" element within the German nation. ${ }^{27}$ Patriotic sentiment was not the only reason, then, for the Jewish population's overt enthusiasm in support of the war effort. German-Jewish men and women, like their fellow Jews in France, saw the war as an opportunity to prove that they belonged to the nation and to gain the approval of non-Jewish society. ${ }^{28}$ Henriette Fürth,

\footnotetext{
${ }^{23}$ Margarete Susman, “Der Krieg und das Wort Gottes,” Neue Zürcher Zeitung, Aug. 16, 1914.

${ }^{24}$ Margarete Marasse, "Der heilige Krieg," AZJ, Sept. 1914.

${ }^{25}$ Mendes-Flohr, "Im Schatten des ersten Weltkrieges," 19.

${ }^{26}$ Siegmund Katz, "Ihr Enkel der Makkabäer," AZJ, Sept. 1914.

${ }^{27}$ This attitude became even stronger during the war. See, e.g., Sven O. Müller, Die Nation als Waffe und Vorstellung. Nationalismus in Deutschland und Großbritannien im Ersten Weltkrieg (Göttingen: Vandenhoeck \& Ruprecht, 2002), 160. A closer look at the German Social Democratic Party shows that it was also indifferent to the Judenfrage (Jewish Question): the party's "publicly articulated anti-antisemitism very quickly dries up to little more than a barely discernable trickle." See Lars Fischer, The Socialist Response to Antisemitism in Imperial Germany (New York: Cambridge University Press, 2007), 17

${ }^{28}$ Emily Machen, "Soldiers of Faith behind the Lines: Religious Women and Community Patriotism during the First World War in France," Women's History Review 22, no. 1 (2013): 31-50. The argument that Jews had to earn equal rights or social recognition had its roots in the emancipatory discourse of the late eighteenth century. See, e.g., Naphtali H. Wessely, Divrei Shalom ve-Emet (Berlin: n.p., 1782-85).
} 
a Social Democrat, JFB member, and one of the day's most influential women's rights campaigners and social policy experts, described the reward that German Jews hoped to gain from their war efforts:

We shall believe in the realization of the Kaiser's words. We shall await and hope for it like the arrival of the Messiah. But we shall not thereby forget that any word from the Kaiser, however well-meaning, cannot eliminate all the open or, even less so, latent, concealed antisemitism that is rampant in so many different varieties, spoiling our German national existence. So we must fight this open and concealed antisemitism through our deeds-not by an act of defense. The times are too hard and our energies too precious for that today. Instead, we must prove by every one of our words and actions that we, too, belong inseparably and self-evidently to the German community; that we are no foreign drop in the [German] blood but an organic component of the German people. ${ }^{29}$

Many Zionists, most of whom were members of the Zionistische Vereinigung für Deutschland (Zionist Organization for Germany), were, for obvious reasons, less intent on achieving complete integration into German society. Still, large numbers of them served both on the front lines and on the home front. In transnational solidarity with their fellow Jews in Russia, and also for less altruistic reasons, German Jews were ambivalent about Russian Jews fleeing pogroms and migrating to Germany; still, they welcomed the fact that war had been declared on "the archenemy of all Jews"- "tsarist Russia"- since a victory by the Moskowitertum would "destroy Jewish and Zionist hopes and achievements." 30

More so than men, Jewish women - many of whom were active in the JFB or in other interdenominational women's associations - shared with non-Jewish women a devotion to a cause that motivated them to make great sacrifices. The German women's movement had, for more than fifty years, more or less emphatically pursued specifically women's issues, and these women now seized the opportunity to gain equal rights. ${ }^{31}$ To that end, both Jewish and non-Jewish women spoke from the earliest days of the war of the "duties of our women and girls to the fatherland." 32 In the early days of August 1914, the Zionist Jüdisch-nationale Frauenvereinigung (Jewish National Women's Organization) also called on female Zionists to "apply your strength to helping and supporting in all areas" while Jewish men were fighting for the German Vaterland. ${ }^{33}$ Many German-Jewish women found themselves, then, confronted with the triple challenge of nation, religion, and gender: they sought complete integration into German society and believed that their demonstration of unconditional loyalty-especially to antisemites-would prove their worth to all men. An initial appeal by the journalist Regina Reißer for cooperation among Jewish women took an almost beseeching tone, as if it were necessary to persuade them to summon up all their courage: "We shall be a united people of sisters, fearing no distress or danger!" 34

Even before the outbreak of World War I, the board of the BDF, which included the JFB chairperson Pappenheim, had started organizing on the home front. On July 31, 1914, BDF chair Gertrud Bäumer - together with Josephine Levy-Rathenau (a cousin of the industrialist

\footnotetext{
${ }^{29}$ Henriette Fürth, "Der Krieg und die jüdischen Frauen," Liberales Judentum, Jan. 1915. On Henriette Fürth, see Angelika Epple, Henriette Fürth und die Frauenbewegung im deutschen Kaiserreich. Eine Sozialbiographie (Pfaffenweiler: Centaurus-Verlags-Gesellschaft, 1996).

${ }^{30}$ Heinrich Loewe, "Feinde Ringsum,” Jüdische Rundschau, Aug. 1914.

${ }^{31}$ Greven-Aschoff, Die bürgerliche Frauenbewegung, 152. In contrast to the moderate middle-class idea that women had to prove themselves worthy in order to gain equal rights, the radical bourgeois and socialist women's movements demanded equal rights unconditionally.

${ }^{32}$ Regina Reißer, "Die Pflichten unserer Frauen und Jungfrauen gegen das Vaterland,” AZJ, Aug. 1914.

33، "Jüdische Frauen!,” Jüdische Rundschau, Aug. 1914.

${ }^{34}$ Reißer, "Die Pflichten unserer Frauen."
} 
Walter Rathenau, who later served as German foreign secretary) and others— set up the Nationaler Frauendienst (National Women's Service, NFD). ${ }^{35}$ Other organizations affiliated with the NFD included the Deutsch-Evangelischer Frauenbund (German-Protestant Women's League, DEFB) and the Katholischer Frauenbund (Catholic Women's League, KFB), as well as women's associations with ties to the unions and the Social Democratic Party. ${ }^{36}$ Within a few days of the NFD's founding, local branches of the organization began springing up all over the country and started implementing with great zeal the work program devised by the BDF, cooperating with local government offices and municipal administrations, the Red Cross, and various local associations. ${ }^{37}$ The three main tasks of the NFD were to ensure constant food supplies, find jobs for unemployed women, and provide social advisory services and welfare to destitute families and those with no male provider. ${ }^{38}$ Almost all social work and the entire welfare system were, by this time, in the hands of women. But the JFB did not operate solely as part of the NFD: it was also actively involved in welfare services for surviving dependents of the fallen (Kriegshinterbliebenenfürsorge), as well as in the German War Graves Commission (Kriegsgräberfürsorge) and the prisoners-of-war welfare organization (Kriegsgefangenenfürsorge). In addition, it acted as a sister service of the Red Cross, the first-aid service for female helpers behind the lines, as well as in military hospitals and in the campaign to fight sexually transmitted diseases. The JFB was socially active in other ways as well. This included the submission of an application to the Prussian military command to shorten store opening times and prohibit the sale of alcohol to military personnel. ${ }^{39}$ Within the Jewish community itself, the JFB pushed for a reasonable diet, distributing throughout Berlin forty thousand leaflets titled Achtet das Brot (Respect the Bread), which called on the population not to waste bread and offered recipes to make use of old bread. ${ }^{40}$ Recognizing the increasing demand for jobs on the part of women who had no male breadwinner, they worked with such women to find solutions. ${ }^{41}$

Other Jewish women's groups and individual Jewish women similarly cooperated on a local and national level with non-Jewish women's groups and government institutions. Organizations such as the Verein für jüdische Krankenpflege (Jewish Nursing Society) and the Israelitische Frauenvereine (Israelite Women's Associations), for example, set up military hospitals in Stuttgart and other cities. ${ }^{42}$ A number of Jewish women even held senior positions within these organizations. The economist Frieda Wunderlich-who later became a professor at the New York School of Social Research-was responsible for training factory social workers. Social welfare expert Siddy Wronsky used her knowledge to write a Handbuch für Kriegsfürsorge (Handbook on the Essentials of Wartime Welfare Work). ${ }^{43}$ Levy-Rathenau and Alice Salomon, a social reformer and educator, supervised female helpers behind the lines on both the Western and Eastern

\footnotetext{
${ }^{35}$ Jürgen Nürnberger and Dieter G. Maier, Josephine Levy-Rathenau. Frauenemanzipation durch Berufsberatung (Berlin: Hentrich \& Hentrich, 2013).

${ }^{36}$ Kundrus, Kriegerfrauen, 100.

${ }^{37}$ Ute Gerhard, Unerhört. Die Geschichte der deutschen Frauenbewegung (Reinbek/Hamburg: Rowohlt, 1990), 296.

${ }^{38}$ Kundrus, Kriegerfrauen, 101-2.

${ }^{39}$ On the JFB's work during the war, see LAB, B Rep. 235-20 MF-Nr. 1199, Helene-Lange-Archiv, "Auszug aus dem Geschäftsbericht 1916/18”; Ernst Fränkel, "Das unbekannte Heer," BJFB, April 1936.

${ }^{40}$ Henriette May, "Rechenschaftsbericht," in Protokoll d. V. Delegierten-Versammlung am Sonntag, den 28. Januar 1917, ed. Jüdischer Frauenbund (Berlin: Jüdischer Frauenbund, 1917), 8.

${ }^{41}$ Stephanie Forchheimer, "Das Heim des Jüdischen Frauenbundes in Neu-Isenburg," in Jüdischer Frauenbund, Protokoll d. V. Delegierten-Versammlung, 33.

${ }^{42}$ Kaplan, The Making of the Jewish Middle Class, 221.

${ }^{43}$ Joachim Wieler, "Siddy Wronsky," in Jüdische Frauen im 19. und 20. Jahrhundert, ed. Jutta Dick and Marina Sassenberg (Reinbek/Hamburg: Rowohlt, 1993), 406-7; Siddy Wronsky and Edmund Friedberg, Handbuch der Kriegsfürsorge im Deutschen Reich. Die wichtigsten Bestimmungen und Einrichtungen auf dem Gebiete der Kriegsfürsorge. Die Kriegsfürsorge in Groß-Berlin (Berlin: Vahlen, 1917).
} 
fronts. ${ }^{44}$ Helene Simon, a social policy and social welfare pioneer, was managing director of the Reichsbund der Kriegsbeschädigten und Hinterbliebenen (Reich Committee for the War-Disabled and Surviving Dependents of the War Dead). ${ }^{45}$ Hedwig Wiener-Flatow ran Berlin's Hauptfürsorgestelle (Main Welfare Office) and, in October 1914, Henriette Fürth opened Germany's first regularly operating wartime kitchen in Frankfurt am Main, which provided cooked meals to the impoverished. ${ }^{46}$ Fürth also managed to convince authorities that ex-servicemen should retain their health insurance after demobilization, and that war-related welfare benefits should not be deducted from women's wages. ${ }^{47}$ Even women who were not associated with any organization became actively involved in the war effort. Among them was Estella Rothschild from Frankfurt, who had served as a medic at the front during the Franco-Prussian War of 1870-1871 and been decorated with the Iron Cross. In 1914, she enlisted once again for service at the front. ${ }^{48}$

Jewish women's contribution to welfare work during the war differed from the voluntary work they had previously performed - and not only in terms of extent and intensity. No longer regarded as the pastime of bored, middle-class housewives, this wartime work had become highly respected by the German public in general. Indeed, it was organized with almost military precision and, when the public and military administration established special units in 1916 to coordinate all women's work-including welfare activities-German women could be sure that social service was "just as essential for Germany's ultimate victory as our military victories in enemy lands." ${ }^{49}$ In this context, tzedakah (charity) was not simply one of the three main duties of Jewish women; rather, it was among the "labors of love" that many Jewish women believed would "one day be inscribed in golden letters in the history of this Great War." 50

\section{Wartime Responses to Antisemitic Agitation}

If the Jewish population had ever believed that the "civic truce" declared among all Germans also included them, they learned otherwise a few weeks after the outbreak of World War I. By midAugust 1914, the Israelitisches Familienblatt (IF), a weekly newspaper written for a petit-bourgeois readership, reported examples of antisemitic propaganda in the journal Deutsch-Soziale Blätter. The articles in question portrayed Jewish women as unpatriotic and avaricious. One told of a Jewish woman who had allegedly expressed her horror at the war; another reported that "a certain Frau Stern from Kassel" had avariciously tried to refuse accommodation to ten Landwehr soldiers because she would only be paid for billeting beginning the following week. ${ }^{51}$ The article in the $I F$ marked the first of many reports on the negative portrayal of Jews, especially of Jewish women, in the German press. ${ }^{52}$ Within conservative and national circles, antisemitism often went hand in hand with a fierce antifeminist attitude, and Jewish women were singled out as a special threat

\footnotetext{
${ }^{44}$ On Alice Salomon, see, e.g., Adriane Feustel, Das Konzept des Sozialen im Werk Alice Salomons (Berlin: Metropol, 2011).

${ }^{45}$ Sabine Klöhn, Helene Simon (1862-1947). Deutsche und britische Sozialreform und Sozialgesetzgebung im Spiegel ihrer Schriften und ihr Wirken als Sozialpolitikerin im Kaiserreich und in der Weimarer Republik (Frankfurt/Main: Peter Lang, 1982).

${ }^{46}$ Henriette Fürth, "Die Zentralküche als Kriegseinrichtung," Archiv für Sozialwissenschaft und Sozialpolitik 89, no. 2 (1915): 466-74.

${ }^{47}$ Helga Krohn, “'Du sollst dich niemals beugen.' Henriette Fürth, Frau, Jüdin, Sozialistin,” in Juden in Deutschland. Emanzipation, Integration, Verfolgung und Vernichtung, ed. Peter Freimark, Alice Jankowski, and Ina Lorenz (Hamburg: Christans, 1991), 339; Hilde Ottenheimer, "Soziale Arbeit," in Juden im Deutschen Kulturbereich. Ein Sammelwerk, ed. Siegmund Kaznelson (Berlin: Jüdischer Verlag, 1962), 839.

${ }^{48}$ Frankfurter Israelitisches Familienblatt, Aug. 1914.

${ }^{49}$ Marie Bernays, quoted in Frevert, Frauen-Geschichte, 157.

${ }^{50}$ Regina Reißer, "Die Erziehung unserer Töchter zu sozialer Hilfsarbeit," AZJ, June 1915.

51 “Der gestörte 'Burgfrieden,"” Israelitisches Familienblatt, Sept. 1914.

${ }^{52}$ Israelitisches Familienblatt, Oct. 1914; see also, e.g., Im deutschen Reich, Jan./Feb. 1915.
} 
to the German nation. ${ }^{53}$ In 1915, Ludwig Langemann, chairperson of the Bund zur Bekämpfung der Frauenemanzipation (League for the Prevention of Women's Emancipation), stated, “The international Jewish nation has taken over the leadership of this trio: semitism, democratism, and feminism. ${ }^{54}$ But German Jews could not do much to counter antisemitic attacks aside from refuting the claims. The IF ran a series on "Voluntary Jewish War Services" and "Jewish War Welfare" in late August 1915 to show that Jewish men and women were, in fact, just as self-sacrificing as the rest of the German public. ${ }^{55}$

The board of the JFB doubted that antisemites could be silenced by Jewish professions of loyalty to the Reich and overzealous participation in the war effort. In 1915, Sidonie Werner, deputy chairperson of the JFB and chairperson of its Hamburg section, warned Jewish women to avoid acting conspicuously, to dress as plainly as possible, and to urge their children to behave in an orderly fashion - as a precaution, so to speak. ${ }^{56}$ Werner thus fell back on the centuriesold Jewish survival strategy of keeping a low profile. Likely as a consequence of this strategy, the JFB abandoned its campaign against Jewish prostitution and female trafficking at the outbreak of the war, even though the remediation of these problems had been one of the organization's high-profile objectives before the war. ${ }^{57}$ Pappenheim had traveled to Galicia, Russia, and the Middle East to see for herself how Eastern European Jews lived, and found many living in misery and squalor, conditions that she believed bred the negative tendencies against which the JFB fought. ${ }^{58}$ Moreover, she was convinced that women's low standing in traditional Judaism and their consequent lack of education had forced many of them into prostitution. ${ }^{59}$ Her attitude toward Eastern European Jews was essentially patronizing, however. Like many German Jews, she regarded them as uncivilized and unable to meet moral, social, or hygienic-i.e., German - standards; it was the task of German-Jewish women, she believed, to familiarize Jewish women from Eastern Europe with German language and culture in order to "improve" their lives. ${ }^{60}$ In its prewar fight to target the causes of female trafficking and prostitution, the JFB had not only taken part in all the relevant international conferences but also shown considerable feminist awareness by demanding modification of what it saw as discriminatory aspects of the halachah, the Jewish law, namely the sections concerning marriage, divorce, and inheritance. More than half of all European Jewish women (and men) lived in the Russian and Austro-Hungarian empires, where they had to get married and divorced according to Jewish law, with no option for a civil marriage. It is important to note that these Jewish laws granted men almost all privilegesonly men could file for divorce, for example-while providing women with almost none. As a consequence, women who found themselves in poor living conditions were easily lured into feigned marriages, and many of them ended up in brothels in Western Europe or

\footnotetext{
${ }^{53}$ Diane J. Guido, The German League for the Prevention of Women's Emancipation: Antifeminism in Germany, 1912-1920 (New York: Peter Lang, 2010).

${ }^{54}$ Ludwig Langemann, "Die Zusammenhänge zwischen Semitismus, Demokratismus, Sozialismus und Feminismus. Vortrag gehalten im Jahr 1915," in Der Deutsche Zusammenbruch und das Judentum, ed. Ludwig Langemann (Munich: Deutscher Volksverlag, 1919), 6.

55 “Freiwillige Jüdische Kriegsleistungen," Israelitisches Familienblatt Hamburg, Aug. 1914; "Jüdische Kriegsfürsorge," Israelitisches Familienblatt Hamburg, Aug. 1914.

${ }^{56}$ Kaplan, The Making of the Jewish Middle Class, 225.

${ }^{57}$ For more on the JFB's activities against female trafficking and prostitution, see Kaplan, Die jüdische Frauenbewegung, 181-248.

${ }^{58}$ Pappenheim detailed her impressions in several books, e.g., Zur Lage der jüdischen Bevölkerung in Galizien. ReiseEindrücke und Vorschläge zur Besserung der Verhältnisse (Frankfurt/Main: Neuer Frankfurter Verlag, 1904); Sisyphus-Arbeit. Reisebriefe aus den Jahren 1911-1912 (Leipzig: Linder, 1924).

${ }^{59}$ Kaplan, Die jüdische Frauenbewegung, 201.

${ }^{60}$ For a closer look at Pappenheim's view of Eastern European Jewish women, see Elizabeth Loentz, Let Me Continue to Speak the Truth: Bertha Pappenheim as Author and Activist (Cincinnati, OH: Hebrew Union College Press, 2007), 123-56.
} 
South America with no possibility of getting a divorce in order to remarry. According to Pappenheim, the lives of "thousands of Jewish girls were ruined every year" by Jewish matrimonial law. ${ }^{61}$

In view of the highly complex and religiously sensitive nature of making amendments to the halachah, the JFB also pursued a more practicable strategy, one that involved creating a safety net for Jewish girls in Eastern Europe and Germany. This included the establishment of hostels, social clubs, comprehensive and vocational schools, a travelers' emergency service, and even a young marriage fund. Many male members of the Jewish community in Germany observed these activities with disapproval and tried, without success, to silence Pappenheim and her fellow campaigners at the JFB. That they did so out of fear of antisemitic propaganda, as they claimed, is doubtful. In any case, the JFB argued that it was compelled to perform this work not only by its feminist principles and sense of "solidarity with all Jews" but also by the pressing need "to take measures against a phenomenon that provided grist to the [mill of] antisemites" by attracting attention to the seamier side of Eastern European Jewry. ${ }^{62}$

During World War I, female trafficking to Western Europe and overseas came more or less to a standstill - unlike prostitution, which was supported and regulated by the military leadership, especially along the Eastern front. ${ }^{63}$ But, as already mentioned, the JFB now seemed to turn a blind eye to the latter. ${ }^{64}$ What caused the JFB to withdraw its long-standing commitment to "improving" the Jewish population in Eastern Europe, especially at a time when German-Jewish men were needed by the German military to serve as mediators between the German authorities and the Jewish population in the occupied territories in Russia and Galizia — and had, as a result, purportedly gained a "better position for negotiating" with the German government to improve the situation of the Eastern European Jews? ${ }^{65}$ This change in the mission of the JFB seems particularly unusual in light of the fact that many relief organizations were being established to that end at just this time, among them the Komitee für den Osten (Committee for the East) founded in November 1914. Had German-Jewish women lost their sense of "solidarity with all Jews" —or at least with those in Eastern Europe? Did they simply give up a battle they had previously considered to be one of their core activities? That was not the case, in fact, as numerous articles by German-Jewish feminist activists such as Henriette Fürth suggest. ${ }^{66}$ They still regarded prostitution as a severe problem but no longer approached it as a social and humanitarian problem solely of Eastern European Jewry. Instead, they blended the issue into the more general German discourse concerning the connection between prostitution and venereal diseases. German authorities and health experts blamed the wartime increase in extramarital sexual contacts (especially between German soldiers and prostitutes) for the spread of venereal diseases, which made them fear for the soldiers' fitness to fight and for the morality of the German population more generally. ${ }^{67}$ The JFB's focus shifted accordingly from the humiliating situation of Jewish prostitutes to the negative medical and social aspects of venereal diseases within German society. In this context, Jewish law-as a potential

\footnotetext{
${ }^{61}$ Pappenheim, Sisyphus-Arbeit, 53.

${ }^{62}$ Ibid.

${ }^{63}$ See Edward J. Bristow, Prostitution and Prejudice: The Jewish Fight against White Slavery, 1870-1939 (New York: Schocken Books, 1983), 285; Sven Rößler, Reglementierung der Sexualität? Frontbordelle und "wilde" Prostitution im Ersten Weltkrieg (Munich: Grin, 2009).

${ }^{64}$ Kaplan, Die jüdische Frauenbewegung, 221-22.

${ }^{65}$ Pulzer, Jews and the German State, 364.

${ }^{66}$ See, e.g., Henriette Fürth, "Die Bekämpfung der Geschlechtskrankheiten, der Krieg und die Schutzmittelfrage im Lichte der Bevölkerungspolitik," Zeitschrift für Bekämpfung der Geschlechtskrankheiten 13/14, no. 16 (1915/16): 301-15; Fürth, "Zur Reglementierung der Prostitution,” Das freie Wort, Oct. 1916.

${ }^{67}$ Lutz Sauerteig, "Militär, Medizin und Moral. Sexualität im Ersten Weltkrieg," in Die Medizin und der Erste Weltkrieg, ed. Wolfgang U. Eckart and Christoph Gradmann (Pfaffenweiler: Centaurus-Verlags-Gesellschaft, 1996), 197-226.
} 
reason for the misfortune of Jewish prostitutes - did not play a significant role. It seems instead that during the war, the JFB and German-Jewish women demonstrated solidarity primarily with the German nation and the German-Jewish community, concentrating their combined resources on the war effort so that no one would doubt their loyalty to the German Reich. In other words, the JFB stopped focusing on the problem of Jewish prostitution in the hope of deflecting potential antisemitic attacks.

The JFB's efforts to disassociate itself from antisemitic stereotypes were part of a dual strategy to construct and convey a positive public image of Jewish women. In this way, the organization hoped to achieve its members' two main wartime objectives: gaining the acceptance and the respect of German society, and winning the right to vote. At the same time, it endeavored to raise its public profile as a specifically Jewish organization and highlight the contribution of Jewish women to the war effort and on the home front. A conflict that arose between Bertha Pappenheim and Helene Lange, chair of the Allgemeiner Deutscher Frauenverein (German Women's Association, ADF), illustrated the obstacles that blocked JFB efforts to attain greater visibility within the women's movement — as well as heightened sensitivity to what was perceived as possibly antisemitic behavior. The conflict was sparked by Lange's 1915 anniversary address marking fifty years of the ADF.

Non-Jewish women in the movement and even some Jewish functionaries feared that highprofile efforts by Jewish women would discredit the entire women's movement, which was already suspected in nationalist and conservative circles of being a Jewish conspiracy. ${ }^{68}$ In her address, Lange retraced the historical development of the German women's movement and referred to the BDF's links with various religious women's associations, mentioning certain Protestant and Catholic organizations specifically but not the JFB. ${ }^{69}$ This was odd, given that the JFB was the largest denominational association within the BDF, which it had joined in 1907, a year before the DEFB. (The KFB had never shown any interest in becoming a member.) Pappenheim was understandably angered at this omission and requested an explanation from Lange. When Lange failed to respond, Pappenheim and the JFB's secretary, Henriette May, demanded a statement from the board of the BDF, clarifying whether they regarded the JFB as a denominational organization of equal value to the other religious women's associations. ${ }^{70}$ The BDF's chairperson, Bäumer, and its secretary, Alice Bensheimer, confirmed that Lange had the same respect for the JFB as she did for the Christian women's organizations and underlined the transdenominational character of the BDF. But that obviously did not extend to the Jewish women's group, the only one within the BDF whose religious identity was repeatedly glossed over. Christianity, by contrast, often played a role in articles featured in the association's publication, Die Frau, some of which were written by Bäumer herself. ${ }^{71}$ In a letter to Bensheimer, Pappenheim wrote freely of her disappointment:

I personally had a great deal of respect for Dr. Bäumer's character because-besides her intellectual abilities, her almost artistic mastery of the spoken and written word-I felt she was fair. Fairness is culture, respecting others and yourself equally. Gertrud has severely disappointed me on this count. With her deftness, it would even have been easy for her to conceal her point of view; but she felt the Jewish women weren't worth the

\footnotetext{
${ }^{68}$ Ute Planert, Antifeminismus im Kaiserreich. Diskurs, soziale Formation und politische Mentalität (Göttingen: Vandenhoeck \& Ruprecht, 1998), 86-88.

${ }^{69}$ Founded in 1865, the ADF was the oldest association within the BDF. Like the JFB, it belonged to the BDF's moderate wing but had only about half the members, i.e., about fourteen thousand in 1913. See Frevert, Frauen-Geschichte, 110. Lange's speech is printed in Die Frau, Jan. 1915.

${ }^{70}$ The entire correspondence concerning this matter is in LAB, B Rep. 235-01 MF 2213-14 Helene-Lange-Archiv.

${ }^{71}$ See, e.g., Gertrud Bäumer, "Protestantischer Geist," Die Frau, Jan. 1917.
} 
trouble - after all, the Jewish women with whom she is used to working are so forbearing and tolerant and discreet! ${ }^{72}$

The BDF dismissed the matter as a private dispute between Lange and Pappenheim and refused to give the JFB the reassurance Pappenheim sought. It did not intervene even after Pappenheim resigned from her office at the NFD, or when unrest began to grow among the Jewish employees of the NFD in Frankfurt am Main. ${ }^{73}$ Pappenheim eventually threatened to take the JFB out of the $\mathrm{BDF}$ or resign as the chair of the JFB, and even made good on her threat by provisionally handing over her post to Sidonie Werner, the deputy chairperson. ${ }^{74}$ The BDF found itself in a dilemma. On the one hand, it wanted to convey the image of a homogeneous women's movement, offering no easy targets for opponents of women's liberation and antisemites to attack. On the other hand, it could hardly afford to lose its largest member organization. Bäumer tried to pacify Pappenheim with an unofficial letter-from "person to person," as she wrote. ${ }^{75}$ When this effort failed, the BDF was forced to concede to Pappenheim's demand. In her function as chairperson of the BDF, Bäumer confirmed the equal value of the JFB in an official letter to its board. From the JFB's perspective, this was sufficient proof that it had achieved its goal of raising the profile of Jewish women in the women's movement. ${ }^{76}$

It is unclear whether Lange's omission in her 1915 speech was motivated by antisemitic sentiments. ${ }^{77}$ By the following year, however, German-Jewish men and women would find themselves experiencing ever more virulent forms of antisemitism. Two years into the war, it was obvious that Germany would not secure a rapid victory, and German morale sank steadily as a result. German victories along the front lines were far less frequent than had been expected and, on the home front, women increasingly struggled with food and fuel shortages. One unfortunate upshot of all this was militant antisemitic agitation. Besides organized forms of public antisemitic vilification (the Reichshammerbund, for example, one of the Empire's most active antisemitic organizations, called for "wartime inquiries" against Jews), this included personal discrimination in the trenches, in welfare offices, and on the streets. ${ }^{78}$ Many Jews also believed that the German government itself was being swayed by the popular antisemitic mood. Two events in particular marked the collapse of the "civic truce," at least with regard to German Jews: the so-called Judenzählung, a 1916 census of Jews in the German army, and the 1918 immigration ban placed on Jews from the East. Both of these had a crucial impact on German Jews' sense of national and personal identity.

The Judenzählung was ostensibly taken to refute antisemitic claims that Jews were avoiding army service. The results of the census were never published, not least because they showed that the ratio of Jews in the military to the total Jewish population was actually slightly higher than that of nonJews. This was the opposite of what the antisemites had contended. German Jews almost

${ }^{72}$ LAB, B Rep. 235-01 MF 2213-14 Helene-Lange-Archiv, letter from Bertha Pappenheim to Alice Bensheimer, Feb. 2, 1916. The extent to which Bensheimer — who was Jewish herself — felt that Pappenheim's last comment was also directed at her is unclear.

${ }^{73}$ LAB, B Rep. 235-01 MF 2213-14 Helene-Lange-Archiv, letter from Eva von Roy to Helene Lange, Feb. 8, 1916.

${ }^{74}$ LAB, B Rep. 235-01 MF 2213-14 Helene-Lange-Archiv, letter from Alice Bensheimer to Elise Hopf, April 25, 1916.

${ }^{75}$ LAB, B Rep. 235-01 MF 2213-14 Helene-Lange-Archiv, letter from Gertrud Bäumer to Bertha Pappenheim, June 20, 1916.

${ }^{76}$ LAB, B Rep. 235-01 MF 2213-14 Helene-Lange-Archiv, letter from Bertha Pappenheim to Alice Bensheimer, June $22,1916$.

${ }^{77}$ On antisemitism in the German women's movement, see, e.g., Susanne Omran, Frauenbewegung und 'Judenfrage'. Diskurse um Rasse und Geschlecht nach 1900 (Frankfurt/Main: Campus, 2000).

${ }^{78}$ See Werner Jochmann, "Die Ausbreitung des Antisemitismus," in Deutsches Judentum in Krieg und Revolution, 1916-1923. Ein Sammelband, ed. Werner Mosse and Arnold Paucker (Tübingen: Mohr Siebeck, 1971), 411; Panter, Jüdische Erfahrungen und Loyalitätskonflikte, 178-89; Kaplan, The Making of the Jewish Middle Class, 225-27. 
unanimously objected to the census, but they were divided over how to respond. They wanted, on the one hand, to articulate their displeasure about such discrimination while continuing to defend the honor of Jewish soldiers and their families; on the other hand, though, they did not want to weaken the government headed by Theobald von Bethmann Hollweg, the German chancellor from 1909 to 1917, whom they saw as a safeguard against the nationalist Right. The $\mathrm{CV}$ and other Jewish organizations decided that it was the wrong moment to fuel any doubts about the unconditional loyalty of German-Jewish men and women. ${ }^{79}$ The JFB, by contrast, agreed with the Zionists for once and issued a statement, formulated at a delegates' conference in 1917, that condemned the census in no uncertain terms. They nevertheless announced that Jewish women would "in the future continue undeterred to fulfill their duties to the fatherland, which are so dear to them, and not be shaken in their commitment to Germany's victory and greatness." ${ }^{80}$ The conference's opening speech by Sidonie Werner implored women to act in a strictly patriotic manner: "To bear quietly what has been done to us as Jews is now our highest duty to the fatherland; we shall grit our teeth, hold out, strain to the utmost to continue to do our duties, suppress all expressions of indignation, integrate ourselves, as we have done in the past, in the great army at and behind the front lines, to the advantage and benefit of the fatherland." 81 To disprove the antisemitic accusations, Werner continued, women would have to perform their duties for the fatherland all the more zealously "as self-aware, upright Jewish women." 82 But she also added that Jewish men and women should make these sacrifices in order to be in a better position to demand better treatment after the victory of the German Reich: "We shall no longer tolerate mistreatment and torment when the great moment of liberation has come for our beloved fatherland." 83

Despite these appeals for perseverance, the JFB was, in fact, beginning to show some signs by late 1916 of a partial withdrawal from general social work activities, largely because of the increase in antisemitism. That very year, Pappenheim noted a "disunity within Jewry" that stemmed from a "lack of solidarity" at a moment "calling for the utmost mustering of community feeling, for the will to live, and for determined resistance against enemies." 84 According to Pappenheim, the time had come for Jewish women to get involved "in all important and responsible positions of Jewish community life." 85 To that end, she designed a self-contained Jewish welfare system that grew to become the Zentralwohlfahrtsstelle der deutschen Juden (Central Welfare Office of the German Jews). The office coordinated all aspects of Jewish social work beginning in 1917, and thus anticipated the fragmentation of German society that would follow in the postwar years. Despite this gradual turn inward, the JFB nevertheless continued to adhere in general to the policies of the BDF with respect to the war effort. It issued rallying calls, decried all armistice offers, and tried to convince its members to keep up their efforts in support of the war. As Fürth put it, "We abhor war now as we did in the past, but we nevertheless approve of the struggle we have been forced into and are prepared to sacrifice ourselves with all our worldly possessions, with body and soul and to the last drop of blood, to ensure our victory, and with this victory, to conclude a peace in which Germany at last

\footnotetext{
${ }^{79}$ On the effect of this census, see, e.g., Walter T. Angress, “The German Army’s 'Judenzählung' of 1916: Genesis Consequences - Significance," Leo Baeck Institute Yearbook 23, no. 1 (1978): 117-37; Jacob Rosenthal, "Die Ehre des jüdischen Soldaten.” Die Judenzählung im Ersten Weltkrieg und ihre Folgen (Frankfurt/Main: Campus, 2007).

80 "Mitteilungen. Jüdischer Frauenbund E.V.," Die Frauenbewegung, Jan. 1917.

${ }^{81}$ Sidonie Werner, "Eröffnungsrede am 5. Delegiertentag des Jüdischen Frauenbundes,” AZJ, Feb. 1917.

${ }^{82}$ Ibid.

${ }^{83}$ Ibid.

${ }^{84}$ Bertha Pappenheim, “Weh’ dem, dessen Gewissen schläft!," AZJ, Dec. 1916.

${ }^{85}$ Ibid.
} 
brings the blessings of humane culture and civilization to all." 86 As late as 1917 , loyalty to the nation clearly remained an overriding motivation for middle-class German-Jewish women.

\section{The Evolution of the JFB during the Weimar Years}

Whether the war had a liberating effect on women is rightly disputed. German (and GermanJewish) women nevertheless earned a major victory immediately after the conflict ended in 1918: female suffrage, which had been one of the principal demands of the women's movement and of the JFB. Besides the political changes it signified, the right to vote heralded radical social changes and previously unimagined possibilities for female self-fulfillment. Women had, by necessity, filled the vacancies left by conscripted male doctors, train conductors, and tram operators (to name just a few of the occupations they had entered during the war), but after 1918, the majority of returning men resumed their posts. The women who could afford to do so returned to their households and more or less willingly let their husbands - those who had survived-become the breadwinners once again. The academic and professional worlds could hardly remain closed to young women, however, given that the male population had been reduced so dramatically. Many young Jewish women, in particular, were keen to take advantage of the new opportunities that had become available in the postwar years. ${ }^{87}$

At the same time, however, Germany's defeat was perceived by middle-class German-Jewish women as a national disgrace; they, too, suffered under the harsh consequences of the war and the Versailles Treaty. Like all Germans, they had to cope with the death of male relatives or with men who had returned home bearing serious physical injuries and psychological traumas. Widows with young children had to provide for their families alone; hunger and poverty were widespread, and the hopes women had nurtured for their country had been dashed in the last years of the war. Expecting to belong to a triumphant Germany, they had instead become part of a defeated and humiliated nation, made to bear the bitter consequences. Still, the inclusion of fallen husbands, fathers, and brothers in the national commemoration of the military dead through the late 1920s must have offered some consolation: it meant that they were accepted into a German community of mourning. ${ }^{8}$

Those Jews who had hoped for complete integration into German society and who had worked toward that end on the home front nevertheless felt bitter disappointment and were forced to admit that they had been mistaken in many respects - that they had toiled, suffered, and kept quiet in vain. Even while the war was still raging, a conceptual transition had started to take shape in the country's collective consciousness as a nation. The idea of the home front gave way to that of a German national community, defined above all by its aggressive disassociation from groups perceived to be "different"-including Jews. Rumors of Jewish profiteering from the war were still rampant, and Judaism became virtually synonymous with profiteering on the food market. ${ }^{89}$ German Jews looked on helplessly as their efforts and sacrifices for the German homeland were met with an increasingly antisemitic mood. Along with the Judenzählung, the German government's introduction in 1918 of immigration controls on Jewish people from the East marked a sobering moment even for the most patriotic Jews. After 1918, the spread of the so-called stab-in-the-back legend and the circulation of inflammatory antisemitic slogans

\footnotetext{
${ }^{86}$ Henriette Fürth, Die deutschen Frauen im Kriege (Tübingen: Mohr, 1917), 59.

${ }^{87}$ See, e.g., Harriet Pass Freidenreich, Female, Jewish, and Educated: The Lives of Central European University Women (Bloomington: Indiana University Press, 2002).

${ }^{88}$ Grady, The German-Jewish Soldiers, 221-22.

${ }^{89}$ See, e.g., Davis, Homes Fires Burning, 133.
} 
alleging that the Jews were collectively to blame for Germany's defeat made matters even worse. ${ }^{90}$ Whereas antisemitism had been a "social norm" and a subtle "cultural code" in the German Empire, it became, during the war years and the Weimar Republic, a "political-programmatic and aggressive attitude" characterized by its "brutality and broad impact." ${ }^{1}$ It is no wonder that a sense of crisis prevailed among German Jewry even during the so-called Golden Twenties - at the same time that Jews were gaining unprecedented opportunities for the creation of and involvement in a new democratic state and civil society. ${ }^{92}$

German Jews drew different conclusions from such experiences, as a 1918 speech by Eugen Fuchs, chair of the CV, clearly suggested: "We should restrain ourselves and protest loudly, we should disavow and unite. 'Be quiet!' some shout; 'Get ready for action, especially the C.V.!,' others shout." ${ }^{93}$ In general, though, most German Jews tried to ignore the growing antisemitism, investing all their energy and hopes instead into the formation of a more democratic German society. While exceptional, the careers of politicians such as Walther Rathenau and the prominent Prussian civil servant Hermann Badt demonstrated that the Weimar years did indeed open doors to many Jews who supported the fledgling republic. To a lesser extent, the same held true for young Jewish female academics, whom Harriet Freidenreich has dubbed "Jewish New Women." Few of these women were interested in Jewish affairs per se, or in joining Jewish organizations. ${ }^{94}$ The lawyer and high-ranking judge Marie Munk, one of the leading experts on family law during the Weimar years, and the successful pediatrician Hertha Nathorff were just two of many female Jewish professionals who worked toward building Germany's civil society without becoming members of Jewish organizations. ${ }^{95}$ Others- such as CV officials Eva Reichmann and Margarete Mühsam-Edelheim-combined their commitment to a new Germany with concern about the situation of German Jews, and considered the battle against antisemitism to be a fight for a Germany that could remain a Heimat for Jews. ${ }^{96}$

There were other responses as well. For example, Margarete Turnowsky, a champion of the rights of immigrants and refugees, and the pioneering social worker Siddy Wronsky reacted to growing antisemitism by turning instead to Zionism. ${ }^{97}$ This response had already begun during the war, and membership in the Zionistische Vereinigung für Deutschland more than doubled from nine thousand in 1912-1913 to twenty thousand by 1921. ${ }^{98}$ Zionist girls' clubs (Zionistische Mädchenklubs) began to form (e.g., in Breslau in 1916, and in Berlin in 1917) and soon became so numerous that they united in 1917 to form a German-wide Zionistischer Mädchenbund (Zionist Girl's League). ${ }^{99}$ Beginning in 1923, the Bund Zionistischer Frauen (League of Zionist Women, BZF) served with its 850 members as an umbrella organization for all German female

\footnotetext{
${ }^{90}$ Pulzer, "Der Erste Weltkrieg," 379.

${ }^{91}$ Shulamit Volkov, Antisemitismus als kultureller Code. Zehn Essays (Munich: C. H. Beck, 2000); Helmut Berding, Moderner Antisemitismus in Deutschland (Frankfurt/Main: Suhrkamp, 1988), 214.

${ }^{92}$ Martin Liepach, "Das Krisenbewusstsein des deutschen Bürgertums in den Goldenen Zwanzigern," in Juden, Bürger, Deutsche. Zur Geschichte von Vielfalt und Differenz, 1800-1933, ed. Andreas Gotzmann, Rainer Liedtke, and Till van Rahden (Tübingen: Mohr Siebeck, 2001), 395-417.

${ }^{93}$ Eugen Fuchs, Um Deutschtum und Judentum. Gesammelte Reden und Aufsätze (Frankfurt/Main: Kauffmann, 1919), 360-61.

${ }^{94}$ Harriet P. Freidenreich, "Die jüdische "Neue Frau” im frühen 20. Jahrhundert," in Deutsch-jüdische Geschichte als Geschlechtergeschichte. Studien zum 19. und 20. Jahrhundert, ed. Kirsten Heinsohn and Stefanie Schüler-Springorum (Göttingen: Wallstein, 2006), 132.

${ }^{95}$ Marion Röwekamp, Marie Munk. Rechtsanwältin - Richterin - Rechtsreformerin (Berlin: Hentrich \& Hentrich, 2014).

${ }^{96}$ Cornelia Hecht, Deutsche Juden und Antisemitismus in der Weimarer Republik (Bonn: Dietz, 2003), 12.

${ }^{97}$ On German-Zionist women's organizations, see Tamara Or, Vorkämpferinnen und Mütter des Zionismus. Die deutschzionistischen Frauenorganisationen (1897-1938) (Frankfurt/Main: Peter Lang, 2009).

${ }^{98}$ Hagit Lavsky, Before Catastrophe: The Distinctive Path of German Zionism (Detroit, MI: Wayne State University Press, 1996), 34.

${ }^{99}$ Jüdische Rundschau, Feb. 1917, April 1917, Feb. 1918.
} 
Zionists. ${ }^{100}$ The charters of these Zionist organizations declared their mission to be "internal Jewish work" and "Zionist education"-without mentioning any particular commitment to Germany or German society as a whole. ${ }^{101}$ Apart from functioning as a response to militant antisemitism, part of Zionism's strong appeal for young Jewish women lay in its support — at least in theory - of equality between the sexes. ${ }^{102}$ That said, this growing enthusiasm for Zionism did not result in a rising number of German Jews making aliyah - that is, migrating to Palestine. Between 1920 and 1932, only 3,306 Jews emigrated from Germany to Palestine. ${ }^{103}$ The number of migrants reached its peak in 1925, when 963 Jews moved to Palestine as a delayed response to the hyperinflation in Germany, as well as to positive reports from Palestine. It subsequently dropped once the German economy stabilized and Palestine began to experience an economic depression. The actual readiness of German Jews to emigrate during the Weimar years was thus more dependent on the economic situation in Germany and Palestine than on the level or awareness of an antisemitic threat in Germany.

Finally, many German Jews reacted to the rising tide of antisemitism by withdrawing into a familiar German-Jewish social and cultural milieu. This seems to have been the reason why many elderly, middle-class Jewish women became members of the JFB, whereas only a few young women joined. The younger generation remained interested in women's issues and gender equality even after female suffrage had been introduced, but they considered the bourgeois women's movement and its moderate program to be anachronistic. Marion Kaplan suggests that younger women tended to join professional or Zionist youth associations instead. ${ }^{104}$ Moreover, the altered demographic and economic situation after the war meant that many more of them were by then engaged in full-time employment or academic study and thus did not have the time to attend the JFB's daytime meetings, which were arranged to suit the routines of middleclass housewives. The JFB responded to this challenge by launching its own youth group in 1926, but its failure to recruit members made it evident to the JFB that the younger generation no longer considered it - or other pioneering women's organizations - to be relevant to their needs. ${ }^{105}$

The JFB's main clientele remained older, financially affluent housewives and unmarried women. For them, the humiliating experience of the war-an outright rejection by nonJewish Germans of their enthusiastic commitment to the German fatherland-had been too profound to ignore, and their clouded relationship with non-Jewish Germans strongly suggested that complete integration German society remained out of reach. Because these women did not have professional careers, joining professional associations was not an option, and they did not, as a rule, relate to the Zionist movement. For all of these reasons, they joined the JFB instead, which led to a steep rise in membership over the course of the 1920s. Available archival sources do not indicate whether these new members were feminists who had previously belonged to other women's organizations, or whether politically apathetic Jewish housewives suddenly developed a moderate

\footnotetext{
${ }^{100}$ Margarete Turnowsky, “Zionistische Frauenarbeit,” Jüdische Rundschau, Dec. 1924.

${ }^{101}$ Ibid.

${ }^{102}$ See, e.g., Michael Berkowitz, “Transcending ‘Tzimmes and Sweetness': Recovering the History of Zionist Women in Central and Western Europe, 1897-1933," in Active Voices: Women in Jewish Culture, ed. Maurie Sacks (Urbana: University of Illinois Press, 1995), 41-62; Claudia T. Prestel, "Frauen und die Zionistische Bewegung (1897-1933). Tradition oder Revolution?," Historische Zeitschrift 258, no. 1 (1994): 29-71.

${ }^{103}$ Doron Niederland, "Emigration Patterns of German Jews, 1918-1938" (Ph.D. diss., The Hebrew University, 1988), 21-23. The gender and class of those 3,306 people are not known.

${ }^{104}$ She does not mention numbers, however. See Kaplan, Die jüdische Frauenbewegung, 47, 119-20.

${ }^{105}$ Adelheid Kulp, "Zur Frage des Nachwuchses in der sozialen Frauenarbeit,” BJFB, Jan. 1928. The JFB was no exception, given that the women's movement had problems in general recruiting young members. See Gerhard, Unerhört, $370-72$.
} 
feminist streak that prompted them to join the JFB. It is more likely that growing antisemitism engendered a widespread desire to engage with like-minded people for the good of the Jewish community. They may have actively sought a Jewish Gemeinschaft, but the majority of these women did not turn their backs in emotional terms on the German nation. Up until at least 1932, they still perceived themselves as Germans with "only one fatherland ..., and this is Germany!" 106 They wanted to create a sense of community based on "Jewish culture-Jewish ethics - all aspects of the Jewish model," but "in combination with the values of German culture" and without denying their German identity. ${ }^{107}$ Their focus on Jewish affairs did not signify a rejection of everything German, then, but rather the embracing of a specific GermanJewish identity. ${ }^{108}$

In short, the JFB's program during the Weimar years emphasized a predominantly GermanJewish agenda, and, to that end, the organization became actively involved in working toward international reconciliation in the 1920 s. In so doing, it distanced itself from the BDF, which pursued a more nationalist program-one closer to the German political mainstream. ${ }^{109}$ The JFB leadership gave two reasons for its pacifist involvement: that, as a feminist organization, there was a "natural connection between motherhood and peace," and that, as a Jewish organization, it considered antisemitism to be a threat to world peace. ${ }^{110}$

The agenda of the JFB also changed in a number of other important ways after World War I. For example, it abandoned its strictly anti-Zionist stance, instead opening itself up to Zionist activities and initiatives. In fact, almost all the members of the newly founded BZF joined the JFB after the war, but their influence on the JFB's official policy remained limited-primarily because of Bertha Pappenheim's continuing dominance. She clearly prioritized feminist issues and considered Zionism to be an irreligious, misogynist movement that only fueled antisemitism. ${ }^{111}$ In 1923, the JFB nevertheless signed a pro-Zionist resolution stating that Palestine was the Jewish national home and that all Jews should support the settlement of Jews there. ${ }^{112}$ But the JFB did not regard Zionism as a possible alternative to the diaspora existence of German Jewry and continued to oppose the emigration of German Jews to Palestine until the mid-1930s. ${ }^{113}$

There were other changes as well. Putting a stop to female trafficking and prostitution remained one of the JFB's goals after the war, and it maintained agencies and continued to attend international conferences to that end. But, for a number of reasons, it was no longer the JFB's primary concern - or, at least, one that it highly publicized. In the first place, female trafficking and prostitution declined after the war as trade routes were cut off and a more relaxed postwar approach to sexuality emerged. ${ }^{114}$ The JFB's decision not to publicize its relief work on behalf of Eastern

\footnotetext{
${ }^{106}$ Margarete Fried, “Wir deutschen Juden,” BJFB, Oct. 1932.

${ }^{107}$ Paula Nassauer, "Welche sind die treibenden Kräfte im Jüdischen Frauenbund?,” BJFB, Jan. 1925.

${ }^{108}$ On the cultural aspect of such a specific German-Jewish identity, see Michael Brenner, The Renaissance of Jewish Culture in Weimar Germany (New Haven, CT: Yale University Press, 1996).

${ }^{109} \mathrm{JFB}$ members were active in the peace movement, and the JFB's monthly journal published reports and announcements by the Women's International League for Peace and Freedom; see, e.g., BJFB, Aug. 1926.

${ }^{110}$ Hannah Karminski, "Generalversammlung des Bundes Deutscher Frauenvereine in Leipzig," BJFB, Feb. 193; BJFB, Aug. 1926.

${ }^{111}$ Loentz, Let Me Continue to Speak the Truth, 61-91.

${ }^{112}$ Jüdische Rundschau, Dec. 1924, May 1923.

${ }^{113}$ Monika Richarz, Jüdisches Leben in Deutschland. Selbstzeugnisse zur Sozialgeschichte, 1918-1945, vol. 3 (Stuttgart: Deutsche Verlags-Anstalt, 1982), 215.

${ }^{114}$ Kaplan, Die jüdische Frauenbewegung, 225. This is not an entirely convincing explanation for the JFB's diminished interest in the issue. As Atina Grossmann has shown in her study on the postwar sexual reform movement, large segments of the population were still largely ignorant about sexual matters. Sexuality may have been tentatively addressed in the public domain, but there is no evidence that people's behavior behind closed doors was any less inhibited or that there was, as a result, less of a demand for prostitutes. See Atina Grossmann, Reforming Sex: German Movement for Birth Control and Abortion Reform, 1920-1950 (New York: Oxford University Press, 1995). It should also be noted that the financial and social
} 
European Jewish women had several seemingly contradictory causes. Like other Jewish organizations with a middle-class character, the JFB tried to avoid negative headlines at all costs-just as they had during the war-and thus did not wish to be associated publicly with immigrants from Eastern Europe who were the particular targets of antisemites. ${ }^{115}$ At the same time, the JFB's motivation for helping Eastern European Jews changed after World War I. Before the conflict, the organization had fought female trafficking and prostitution not only as a counter to antisemitic attacks but also on the grounds that "Jews were responsible for one another everywhere." 116 After the war, another argument gained in significance: Western European Jewry was perceived to be under threat - particularly in a demographic sense as a result of assimilation, conversion, mixed marriage, an aging of population, and a declining birth rate. ${ }^{117}$ All of this made Eastern European Jews appear essential for its survival. As Pappenheim argued in numerous articles, speeches, and letters, Jews from Eastern Europe were a "valuable human resource" for the revival of German Jewry and therefore needed to be protected and educated-just not in the media spotlight. ${ }^{118}$

In the context of this debate about the crisis and the renewal of German Jewry, a number of male intellectuals reflected on the role of German-Jewish women and came to a devastating verdict-one that held women responsible for the postwar crisis facing German Jewry. Resuscitating the prewar European discourse on degeneracy (Entartung), Martin Buber believed that German-Jewish women were also characterized by degeneracy, an idea that found increasing support among German Jews during and after the war as a result of the upheaval, insecurity, and growing sense of crisis in the Jewish community. ${ }^{119}$ In this vein, Hans Goslar-a Zionist journalist who served as chief press officer in the Prussian State Ministry-accused women of taking on "some activity" (social or professional work) to compensate for the alleged emptiness of their life. In his view, they no longer had "a natural relationship to children, nature, or loneliness," and thus jeopardized the existence of the Jewish family and of Jewish tradition. ${ }^{120}$ Max Nordau, one of the leading figures in Cultural Zionism, a branch of Zionism that focused on the revival of a Jewish national culture, and the author of the 1892 book Entartung, offered a simple solution for the problems of the Westjüdin: she needed to follow the role model presented by the Ostjüdin, who "has a high and distinguished position in culture, since she is humble and content to be the appendage of the man and to accept his material superiority."121 Such opinions reflected the fear that met the emergence of the "New Woman," the provocative image of a single, emancipated, independent, sexually liberated female who symbolized Weimar's rapidly changing society. ${ }^{122}$ It is ironic, of course, that in Jewish prewar discourse, Jewish "New

\footnotetext{
situation of Jewish women in Eastern Europe, as well as of female Jewish immigrants in Germany-i.e., precisely the areas where the JFB had initially sought improvement—had worsened, making it likely that even more women were driven to prostitution. See Naomi Shepherd, A Price below Rubies: Jewish Women as Rebels and Radicals (Cambridge, MA: Harvard University Press, 1993), 240-41.

${ }^{115}$ Avraham Barkai, "Jüdisches Leben in seiner Umwelt," in Deutsch-jüdische Geschichte in der Neuzeit, vol. 4, Aufbruch und Zerstörung, 1918-1945, ed. Michael A. Meyer (Munich: C. H. Beck, 1997), 64.

${ }^{116}$ Loentz, Let Me Continue to Speak the Truth, 128.

${ }^{117}$ See, e.g., Mitchell B. Hart, Social Sciences and the Politics of Modern Jewish Identity (Stanford, CA: Stanford University Press, 2000).

${ }^{118}$ See, e.g., Pappenheim, Sisyphus-Arbeit, 64.

${ }^{119}$ Martin Buber, "Das Zion der jüdischen Frau," Die Welt, April 1901; Sharon Gillerman, Germans into Jews: Remaking the Jewish Social Body in the Weimar Republic (Stanford, CA: Stanford University Press, 2009), 2.

${ }^{120}$ Hans Goslar, Die Sexualethik der jüdischen Wiedergeburt. Ein Wort an unsere Jugend (Berlin: Jüdischer Verlag, 1919$), 10$.

${ }^{121}$ Max Nordau, Die conventionellen Lügen der Kulturmenschheit (Leipzig: Schlicke, 1884).

${ }^{122}$ Katharina von Ankum, Women in the Metropolis: Gender and Modernity in Weimar Culture (Berkeley: University of California Press, 1997), 1-12.
} 
Women" were condemned for no longer seeming Jewish—whereas the later German debate maligned "New Women," at least in part, for being typically Jewish. ${ }^{123}$

Such ideas contrasted starkly with the wartime experience of many bourgeois Jewish womenthat of being vitally important for German society and the Jewish community, a new role that had significantly boosted their self-confidence. Even Zionist women who did not, in general, oppose too intensely their marginalized role within the movement (even though Zionism promised equal rights for women, in theory) could not recognize themselves in these male fantasies. ${ }^{124}$ Because the war had demonstrated to many German-Jewish women that they were capable of autonomous decision making and of organizing affairs outside the household, they now sought more influence within the Jewish community itself - to the chagrin of a number of male leaders of that community. Claudia Prestel calls these self-assured women committed to Jewish affairs "New Jewish Women"-in contrast to the Jewish "New Women" who were indifferent to religion. ${ }^{125}$

The involvement of the JFB in the Central Welfare Office beginning in 1917 was one example of this new self-confident participation in Jewish politics. ${ }^{126}$ As a result of such activities, social welfare was no longer perceived as a playground for middle-class housewives; it came to be accepted as a professional field offering serious career opportunities for German-Jewish women. It is something of a paradox that the emergence of these newly professionalized social workers led to a further line of generational and ideological conflict within the JFB. The older generation had used the concept of gender difference to justify their vocation for welfare work: in their view, "spiritual motherhood" (geistige Mütterlichkeit) qualified all women to perform welfare work. They were now confronted by young women who had studied social work and who based their expertise on "scientific" knowledge instead of maternal instinct. This new generation of females viewed social work as their livelihood, not as a vocation in the Weberian sense of the term. Neither willing nor able to work on a voluntary basis because-unlike many members of the JFB - they had to support themselves financially, they challenged the general attitudes of the older generation, complaining of the latter's insistence on "self-discipline, depersonalization, [and] asceticism" as the essential qualities of a good social worker. ${ }^{127}$ The JFB was well aware of the fact that the bored middle-class daughter was a dying breed and that contemporary economic and social circumstances demanded professional welfare work. But it claimed that female nonprofessionals were just as essential for social work, for only they could ensure that humane (i.e., "feminine") qualities would come to the fore. ${ }^{128}$ Along these lines, Pappenheim criticized professional social work as a "cash cow" (Milchkuh) that lacked "humane warmth." ${ }^{129}$ Moreover, she valued social work as a means of "improving" the character of privileged middle-class women and thus worried about the decline of this therapeutic activity. ${ }^{130}$

\footnotetext{
${ }^{123}$ Atina Grossmann, “The New Woman and the Rationalization of Sexuality in Weimar Germany,” in Powers of Desire: The Politics of Sexuality, ed. Ann Barr Snitow, Christine Stansell, and Sharon Thompson (New York: Monthly Review Press, 1983), 153-72.

${ }^{124} \mathrm{~A}$ number of women responded to a misogynistic article published in 1917 by the journalist Franz Sachs in the influential Zionist magazine Der Jude. See Franz Sachs, "Von deutschen Jüdinnen," Der Jude, Jan. 1917. Some of the letters to the editor were printed in Der Jude. See, e.g., Hildegard Krohn, Martha Epstein, and Johanna Simon-Friedberg, "Von deutschen Jüdinnen," Der Jude, March 1917.

${ }^{125}$ Claudia Prestel, “The 'New Jewish Woman' in Weimar Germany," in Jüdisches Leben in der Weimarer Republik / Jews in the Weimar Republic, ed. Wolfgang Benz, Arnold Paucker, and Peter Pulzer (Tübingen: Mohr Siebeck, 1998), 135-56. Since neither the term Jewish New Women nor the term New Jewish Women was used as an attribute in contemporary Jewish discourse, this article also refrains from using them in order to avoid confusion.

${ }^{126}$ See Gillerman, Germans into Jews, 80-84.

${ }^{127}$ Hannah Karminski, “Aussprache jüdischer Frauen über Erziehungsfragen, Frankfurt am Main, 1-3 Jan. 1929," BJFB, Feb. 1929

${ }^{128}$ Else Cohn, "Soziale Arbeit und Jugend," BJFB, Jan. 1928.

${ }^{129}$ Bertha Pappenheim and Professor Türk, "Aussprache," BJFB, Aug. 1929.

${ }^{130}$ Ibid.
} 
Another line of generational conflict that emerged within the JFB after the war came to light in 1929 at a JFB conference on education. ${ }^{131}$ Attacking Pappenheim and other older members for their lack of faith in morally "imperiled young people," younger members demanded that their charges in the JFB's orphanages and homes for wayward young women be allowed greater freedom-for example, the right to meet young males under adult supervision. Hanna Karminski, a JFB board member, was among those who argued that it would benefit young women if they were not isolated but instead able to strengthen their "sexual reliability" by learning to deal with young men. Pappenheim was relatively progressive when it came to questions involving sexuality, but she nevertheless insisted on keeping young men and women apart. On the basis of her experience in the Gefährdetenfürsorge (a welfare service for "imperiled" young people), she did not feel that the young were able to assess such situations properly. In her eyes, the proposals of these younger social workers were irresponsible and demonstrated a lack of common sense. Despite the fact that young middle-class women were joining the ranks of newly professionalized social workers in increasing numbers during the Weimar years, Pappenheim and the older generation still had the final say. As a result, a patronizing approach continued to dominate German-Jewish welfare policy after World War I, especially when dealing with the main clientele of Jewish social welfare- namely, Jewish refugees from the East, who, they believed, were uneducated, unwashed, and in need of civilization; that view had been confirmed during the war for Pappenheim, Salomon, and other Jewish women who had helped behind the lines in Eastern Europe, and their commitment to it did not waver after $1918 .{ }^{132}$

\section{Conclusion}

Go if you will and count them. Count, too, those buried

And those crippled by this horrific war.

Go there and count. Our help you shall have

To count, too, the Jewish alms

And Jewish fighters for the home victory.

And when anon history's judgment passes,

'Tis you, not we, were found too slight.

We fear not the light of truth,

Whose rays break through the night of times

We walk upright to the future land.

— Henriette Fürth, Judenzählung, $1917^{133}$

The majority of middle-class German-Jewish women contributed enthusiastically and vitally to the war effort on the home front and behind the lines. In so doing, many gained a greater sense of integration within the German nation. Individually or in groups, they organized wartime welfare work on a national and a local level, raised funds, set up war kitchens, cared for the injured in field hospitals, and performed many other important tasks. For the most part,

\footnotetext{
${ }^{131}$ For the complete minutes, see Karminski, "Aussprache jüdischer Frauen über Erziehungsfragen,” 3.

${ }^{132}$ See, e.g., Alice Salomon, "Vom Leben deutscher Helferinnen in einer östlichen Etappe," Die Frauenfrage. Zentralblatt des Bundes deutscher Frauenvereine, Nov. 1917; Bertha Pappenheim, "Kleine Reisenotize," Frankfurter Israelitisches Gemeindeblatt, Feb. 1936.

${ }^{133}$ Henriette Fürth, “Judenzählung," Liberales Judentum, Jan. 1917.
} 
the NFD-affiliated JFB coordinated the work of Jewish women, who offered their services for three main reasons: as patriotic German citizens, they wanted to help their country to victory; as Jews, they hoped to gain social emancipation and recognition as "equal" Germans; and, finally, as females, they wanted to win the right to vote as a reward for their civic efforts. The latter wish was the only one to be fulfilled, with women being granted the vote for the first time in Germany in late November 1918. Their aspirations as Germans and Jews were bitterly disappointed, however. The defeat of the German Reich brought in its wake poverty and violence, as well as political and social disorientation across the country; antisemitism consequently became a strong political force in the Weimar Republic. This, too, was part of the wartime experience of German-Jewish women, and it had direct repercussions on the JFB, particularly with respect to its size and the composition of its membership, as well as its policies and goals.

The traumatic impact of World War I on older, middle-class German-Jewish women is best illustrated by the JFB's postwar memory politics. Its paper, the $B J F B$, largely avoided the subject of World War I during the Weimar years, confining itself to publishing the occasional apologetic article paying tribute to the bravery and selflessness of Jewish women who had served in the NFD. ${ }^{134}$ These women embodied the words and spirit of a lecture titled "Heimgegangene des Krieges (The Fallen of the War)," given by Rabbi Leo Baeck in February 1919: "Working and looking ahead, that is what is expected of us now."135 Given that most had been through drastic, life-altering experiences and that the war was being fiercely debated elsewhere in the Weimar Republic, their eloquent silence on that issue was in itself a statement. In the 1920s and 1930s, the JFB concentrated instead on fostering a positive sense of Jewish identity among its members - a mission at odds with the often humiliating experience of the war. Committed to promoting a strong Jewish community, the JFB was reluctant to recall that it had once championed the complete integration of Jews into German society-unlike the Reichsbund jüdischer Frontsoldaten (RjF), for example, which tried right up to the 1930s to prove that Jews belonged to the German nation by referring to the experience of World War I. ${ }^{136}$ In light of the events of the war, the organization's former objectives, and what it had actually achieved, the JFB's postwar attempts to create a positive Jewish identity were a defiant response to both the suffering of the past and the explicit rejection of Jews by large and vocal segments of German society.

Conflicts over how to respond to these new economic and social challenges ran along generational and ideological lines, especially as older women joined the JFB in large numbers after the war, making it one of the biggest and most powerful German-Jewish organizations of the Weimar years. Although young women were now a minority in the JFB, they defended their opinions with confidence, not only taking advantage of new educational and professional opportunities, mainly in the field of social welfare, but also daring to question the authority of the older generation, whose members still adhered, in their view, to an outdated concept of femininity and social work. Indeed, many older JFB members could not empathize with the position of young women working for financial reasons, and often considered them ungrateful. The older generation, with Pappenheim as its powerful representative, was nevertheless realistic enough to allow open discussion of controversial topics such as Zionism, the nature of social work, and education-and even agreed to some modification of the organization's earlier stances on these issues.

\footnotetext{
${ }^{134}$ See, e.g., Ernestine Eschelbacher, "Die Arbeit der jüdischen Frauen in Deutschland während des Krieges," Ost und West, May 1919; Bertha Badt-Strauss, "Vor zwanzig Jahren um diese Zeit ... Josephine Levy-Rathenau und der Berliner 'Nationale Frauendienst,"” BJFB, Sept. 1934; Fränkel, "Das unbekannte Heer," 9-11. None of the authors questioned the motivations behind the commitment of these women to the home front.

${ }^{135}$ Leo Baeck, Wege im Judentum. Aufsätze und Reden (Berlin: Schocken, 1933), 383.

${ }^{136}$ See Penslar, Jews and the Military, 188.
} 
Although its membership was aging, the JFB's feminist activities did not shrink to the extent that one might expect. Whereas the scope of the JFB's prewar interests had ranged from the plight of Jewish women in Eastern Europe to cooperation with the German women's movement, it was limited in the postwar years - especially because of the rise of antisemitism - to matters within the Jewish community itself. In fact, a growing desire among many German Jews to withdraw into a Jewish environment turned Jewish communities from places one visited only on the Sabbath or during the high holidays - if at all —into social and cultural centers that ran libraries, schools, adult education centers, employment agencies, hospitals, homes for children and the elderly, and even banks and art collections. ${ }^{137}$ In short, the influence of Jewish communities extended across more and more areas after 1918, and the social life of ever more German-Jewish men and women centered on them. Involvement in the Jewish community consequently had far greater appeal for many Jewish women precisely because it encompassed so many new areas of responsibility, including typically female-dominated areas such as welfare work. For all these reasons, the JFB itself gradually abandoned its bold attempts to tackle external problems-a process that had already begun during World War I. But to conclude from this that the self-confidence of middle-class German-Jewish women had somehow weakened would be incorrect. The experience of the war and the need for reorientation after 1918 forced and enabled many of them to become more involved in the affairs of the German-Jewish community itself and to contribute significantly to shaping public Jewish life in Weimar Germany.

The JFB's strategy for solving the trilemma posed by having to square the circle of competing allegiances - German patriotism, Jewish identity, and feminism — was, then, to remain a moderately feminist organization that sought to improve the situation of Jews in Germany, while, at the same time, strengthening a greater sense of Jewish community. As a result, gaining the acceptance of German society no longer played a major role in the organization's program after 1918. In fact, by calling for international reconciliation and by joining the peace movement, the JFB explicitly distanced itself from the increasingly nationalistic German women's movement. This did not mean that the JFB turned its back on Germany, however, and Zionism never did become a significant force within the organization. The majority of German-Jewish middle-class women continued to perceive themselves as part of the German nation and to view German culture as an inherent part of their identity. The futility of that belief would become abundantly clear, of course, following the demise of the Weimar Republic in the early 1930s.

UNIVERSITY OF VIENNA

${ }^{137}$ Brenner, The Renaissance of Jewish Culture, 36-65. 